\title{
Five Filmmakers In Conversation with Gerald Pratley
}

\author{
By Gerald Pratley \\ Spring 2001 Issue of KINEMA
}

THE NFB's 60 $^{\text {th }}$ ANNIVERSARY has been celebrated leaving behind little of its contemporary production to raise the spirits and create enthusiasm among the Board's many long-time admirers and supporters. Founded in 1939 by the accomplished John Grierson, it has now, like its crown sister, The Canadian Broadcasting Corporation $(C B C)$, drifted far from where it was once anchored and away from what it was as a public service, lost on a sea of indifference and mediocrity. Kinema asked four filmmakers long associated with the NFB, documentary film, and $C B C$, to look back over what has been taking place during past years leading to today's disappointing and empty era. They are Gerald Graham, Grant McLean, Terence Macartney-Filgate, Donald Haig and Allan King. They talked to our associate editor and film historian, Gerald Pratley. In this issue, we publish the first two conversations, with Gerald Graham and Grant McLean.

\section{(1) GERALD GRAHAM}

I think it would be worthwhile to mention first how I became involved with film. I come from a backstage family, my dad had taken tickets with the old Dominion Theatre in Ottawa and ended up running one of the early Edison-Armat Vitascope projectors when they were first using large screen and had a feed-reel and taker and the film went into a basket. He was stationed in the middle of a balcony. You might ask why in heaven's name would he be up there. It was customary at that time to put a projection booth up on the balcony. He was expected to act as the bouncer as well and keep order, so he had some memorable moments, when this film was all over the floor. From there he went through a series of jobs, usually connected with the theatre. One was burlesque in the old casino-theatre in Ottawa. He moved to Repertory, the Galvin Players, from there to vaudeville when it was part of a film show. And that's where he finished his career.

He'd also done some work in film, incidental stuff that was shot in Ottawa, but if your father worked in the theatre, your family had an eccentric life. He was off mornings, he was on for the matinee's, he was home for a brief while, then the evening show and it meant that my mother had no social life whatsoever. I used to go on Friday nights with mother and then go back stage and just chat, and talk about the various kinds of things... I worked with him as I grew up as a stagehand. He had occasion to do special effects which I always used to enjoy. He took delight in telling me how he could get a gun to break a lamp. It turned out to be very simple; you used a rat trap with a hammer on it, out of sight from the audience, and a little fuse wire, so at the moment the gun went off, or preferably it was the silence that gave you a little more time, and then this thing would bang all the glass into smithereens... He did things like a train travelling down the mountainside and that was a cigar box and a flashlight, quite effective. So you can see how my career began.

I was immersed in the film and theatrical background and the relationship between backstage and audience. This gave me a strong sense of human values and the fact that you had to have emotional blowups, it was just a part of this kind of a job in film and theatre and what I learned I never forgot. I was interested in science at the time, I came out of high school in the '30s but nobody offered anything in the way of subsidies to go to university or anything like that, so I took correspondence courses and later established a very good relationship with the people from the National Research Council where I used to take the material for testing and that sort of thing. Anyway, I was fortunate also at the Council to develop a wood gluing technique which they patented. When you work for the government you never saw the results of your patents... but they were impressed.

It was during war time and I was offered a professional post there just about the time I got a call to come over to the new National Film Board and create a control process for them. So I talked it over with my Dad, and he said, "Go, it's show business." It was that simple. I knew that if I stayed at the Research Council, that having the equivalent of a bachelors' degree was nothing. You had to have a $\mathrm{PhD}$, a sort of minimum for the people around there, but I did get an offer also to study at Mount Alison University, but here again the depression years had their effect. So anyway I ended up over at the film board. I was interviewed by 
Raymond Spottiswoode, and Raymond was a rather forbidding person and I think it was the first time in my life I ever felt like a colonial. He wore these very thick glasses and he looked down at you... he had a lot of experience, I think primarily as a director under Grierson, and he was a great person, highly intellectual. He was always coming in and asking for some new set of theoretical tests and it was my job to make sure images were entered on the screen, because the cameras in those days had a little bit of shake to them and that sort of thing, so we set up and copied various kinds of masks and crosses... so we could tell, when they could be projected on top of an image and you could see how much play you were getting. Your only microscope was taken to the theatre and projected. Then cut your 30-time expansion. So coming into the Film Board then for the first time was quite an experience.

I might say that Ottawa during the prewar years was very much a small town. Probably $80 \%$ public servants. They all tended to dress in their uniforms, what we used to call "sincere suits." They were black or blue, they had the blue melton coat, ant they had the grey Homburg hat, and if you were really with it, you wore spats in the wintertime. You could always tell where they came from. Well, they didn't care much for the Film Board, which was laid back. The Research Council wasn't too bad, it was in between, people were rather relaxed, so going into the NFB I felt at home, but in an area of total confusion. People were running every way up and down the hall and the only precious thing in their life was that can of film that was going somewhere. So Raymond gave me a brief indoctrination, I was presented with a milk-case -- this is your chair, carry it everywhere and do not let anyone else use it. So a meeting is called and you picked up your milk-case and went.

The John St. building was filled and cluttered with offices... desks pushed in, virtually everywhere. On one occasion in the early days, I remember going in to speak with somebody in an office and there were two desks, there was virtually no room to get around them and one person at the back and one at the front and I stood there rather stupidly, with my milk case. This was a wooden case with a metal frame into which port bottles used to be placed, this was my mark of seniority I had one. So anyway I stood at the door and I was rather confused, and the person I was going to see said, "Well, come on," and I said, "How do I get in to sit beside you?" And he said, "Don't be stupid, walk across the desk," So I climbed up on one chair, again carrying the milk-case, I walked across two desks, dropped on the other side. Now this was Gilbert and Sullivan at its idiotic best. It was an unreal world so that the conservative attitude of the Research Council, where you did get a desk and a chair and a few other things, kind of shattered you, and you wonder why did I ever get into this sort of an arrangement.

Anyway, setting up a control system was very complicated, because by that time, which would have been ' 42 or ' 43 , the Board was committed to wartime series and it was something like trying to slip a foundation under a building which was in operation without disturbing anybody. Everybody said we must have control, but don't interfere with my work. So we used sensitometric systems, the Hurter and Driffield curves, the gamma sheets, whatever, and this was just a series of densities, greater densities on a piece of film that went through probably every thousand feet. Now that had been installed. The only problem is that no one ever read the strips. They were just piled up with the concept that if we ever get some free time we must look at those strips. The chemical plant down the stairs consisted of about three great wooden tanks, probably spruce, two of them were in action and one of them was being cleaned at that time. It was quite a revelation to me that you had to get inside the tank and shave it because the chemicals raised the fur on the thing and then you took a blow torch and singed it and I never would have thought of doing that but that was the way to do it. If they had any problem with processing, the procedure was to dump everything and make a new batch.

Now by that time, Kodak had introduced some fairly sophisticated systems where by you could replenish a film bath. You did an analysis and you began to see that your potassium was low or whatever was needed, and you had a little drip system. We didn't have that really set up until we got to the Montreal studio where we could really have some fun with it, but we used to do a kind of bath replenishment, incredibly simple things saving the Film Board about the total cost of their chemicals because the stuff wasn't being flushed down the drain. I used to leave home at about seven in the morning. I would be at work at 7:30, because a lot of the work occurred just before the plant could roll, you were looking at everything, seeing if everything was working, were the projectors all aligned and that kind of thing, and I was once in the theatre at about eight o'clock in the morning, and looking back at the screen where the speaker horns were, there was a lady 
sound asleep, she had been camping there for some months. It was that kind of a world, so I reported to personnel, and this lady just got up and put on her kimono and went to the washroom as if she was at home. But you have to realize that housing was extremely tight in Ottawa. The Film Board staff was not overpaid and it was hard to get a room because again these people were not part of the mainstream civil service.

I never had a pair of spats, but there was one way of telling the remnants of the previous motion picture bureau which went back to about 1917, those whom we inherited... the problem with the bureau was that it did some quite good work in the leisurely fashion of the public service of Canada. You certainly would not work after 4 o'clock in the afternoon and in the summer time, you took every holiday. This didn't lend itself to a production load of over 200 titles a year, which had to meet deadlines, had to be delivered. So there was conflict, and Grierson finally had to wangle his way to have them absorbed. They resented this invasion, and probably rightfully so. Their way of life was interrupted. They weren't bad people; they were just good civil servants of the time. And some very talented. Jay Booth Scott, for example was extremely clever in creating equipment, reduction sound printers and we found traces of this, that were real contributions, never had been published and nothing was ever said about it. I've incorporated a few of those things.

The worst day of the week.... At that time we would have been using a single system, Akley field camera probably. You had the cameraman and the director and that was about "the crew"... and they would be out collecting material. Now Grierson, and I give him great credit for this had a marvellous web of contacts in the United States, for getting distribution deals, he knew everybody who should be known and he got an arrangement, he was by that time head of war time information services as well, he wore many hats the film board was just one of them. So he had an arrangement that every week we could get a 20-minute segment in a current American newsreel, so this was our dead line. A lot of material came in late, so that meant if Tuesday was our completion date for the newsreel it would take all day to get all the parts together, you would have to do a lot of original negative cutting at the last moment and then take off your masters and that type of thing. As the person in charge of control, I was there usually from 7:30 'til about 1 a.m. because by then I had to take the package down to the Ottawa station to the milk train leaving then for New York. This is before the days of jet aircraft, but it was the best we could do, it was an exhausting day, but when you work for a person like Grierson there was no excuse. You turned up again at 7:30 the next morning, by now he was there all the time while you were doing this... and there were other film makers around joining us, from Canada and London.

The key person originally was Stuart Legg and he started most of the series because he got them up and running fast. Tom Daly came along in due course, Jim Beveridge, and then of course, Grierson being that kind of person, he could find people almost anywhere, sometimes on the train... the first thing you'd know is you'd have a cameraman coming in, Sammy Orleans, he'd come in for a short while and poster the camera setup we were trying to get and teach the boys a little bit. Canadians weren't very good in newsreels in the early days because we didn't have sharp elbows... he made sure that you got to the front of the unit and this helped immensely in the quality of the work. There was always a constant flow of people.

Before Grierson started, there were almost no Canadians in film who knew anything much about film making other than the few at the motion picture bureau. Grierson started bringing in people who had that feeling about them that they wanted to contribute to film and be film makers and he gave them the opportunities. We should not however overlook Associated Screen News, a company carrying on a newsreel function and you had people like the late Gordon Sparling who was one of the true pioneers of filming in Canada. ASN was doing release print work basically on Hollywood films, but Gordon Sparling was very much involved in advertising, a lot of the very good short films, and they did some war material after 1917 which stood out quite well. But again no one among them had Grierson's drive and pace. Grierson, I guess if I had to describe the people who worked at the Film Board, the categories would be at the one end, those who thought it was just a job, at the other end, the young Canadian firebrands he brought in, those were the disciples. And he used to lecture them endlessly, he had no great interest in technical facilities. To him it was just a necessary nuisance. There was no point in saying that we had a leak in the hypo tank, his response would be "well go fix it." It's none of my business.

We had many well known visitors, Lorne Green, the CBC anchorman, you'd have to think of him as a very young person, not Paul Cartwright as he was later on television, and we had Christopher Plummer, I would 
say that just about that time after the war, we had a repertory theatre and it had people like Chris Plummer, Richard Easton, Emilia Hall, and William Shatner -- and all of them came down and provided voices for us, and they were in and out of the place continuously. And there again you'd have to visualize a group of people, 17 years old... that was our age group. By about 1950 I became director of technical operations and this included all the film libraries and the film vaults that we had collected material with, so that in deciding what to do, it started with the production secretary, which was Jim Beverage, and Jim and his group would be researching ideas and again I would like to put in a point for the distribution branch, sometimes their contribution would be overlooked, but remember they were the field representatives, and they would give us a lot of information about audience response.

You can't underestimate the importance of the distribution network. These were trade union groups, nurses associations, factories, all kinds of places... saying you know, we need a film like that. And that in turn created a market what we used to call a sponsored film, then you could go back to a government department saying here, here's an opening... you could do this or that. And then there was an original program.... In the very early days it wasn't a clear map of the future... it was sketched -- we should do this or do that. But we will be prepared to react to any crisis that turns up. One such was, Grierson became aware of the fact that peace would be declared, and he simply collected everybody together and said we're going to do a two reel film "salute to victory" and you will do it within a hundred and twenty hours because it must be in the theatres by such and such a date. This wasn't horrifying... most of us weren't married, we didn't have to go and explain to anybody why you won't see us for two or three days, but Nick Balla coordinated that and had the authority, to draw in anybody he wanted.

But it was an interesting process in that the commentary was recorded first by well known individuals, then the search began for visuals to fit what they were about, the music was composed to fit, the commentator and the guide track for the whole operation. It was rather remarkable and well coordinated. I don't say that it had a masterly plan. It was more emotional -- you had better get your job done because I have to do this and to do that. But it fell together and we had the prints in all the major theatres when peace was announced. So again you learn other techniques, you don't always have to have a script, sometimes they were a nuisance. But first of all the purpose of the board at that time was to show the public and other audiences abroad what Canada was doing.

I do think we were committed to information programs and the only pictorial information programs available. You had no television and relied on newsreels and other means. I can't ever remember anybody having to rewrite a commentary to slant anything. It was fine when the material was controlled by Grierson. Once we got into the field of sponsored film, there were points of view -- they had their political agendas, and that was a constant fight. After the war years, it was about $70 \%$ money from the government. Various departments saw things as exploitation of my particular branch. We got into the problems of, let's say extolling travel films, which was very necessary.... important way of doing it. But the travel bureau had a totally different concept, they were promoting tourism. Another government department would just be beginning to work on environmental effects, and of course there were conflicts and they had to be resolved between all the parties. I guess we served as arbitrators in that.

But we did what had to be done... and it was a constant battle for Grierson, twelve hours a day, he was involved, he had his weaknesses in a sense, he might get an inspiration of concepts of Kant, this is at eleven o'clock in the morning, then he would call the disciples, fortunately we didn't get called in.... but they would sit on the floor around him and just listen. And he was brilliant speaker; it came from his family background.... his mother in particular. And he would go on and on and this might carry on throughout the afternoon and to his home for part of the evening. It had inspiring effect on young filmmakers, they felt that there was a purpose to their work and this was a stimulus to them, especially during their university years and he concentrated on that. He was very good in his international relations, he knew virtually everyone. His interest in film, I believe came from a Rockefeller grant he had, a travelling scholarship, and that introduced him to Hollywood. And I understand that it was Walter Lipmann who persuaded him to give up the printed word and get into film.

You see Grierson was a people-oriented person when he came out of England, and then he became totally devoted to the film as a means of expression. I was saying how the distribution side tended to be ignored, 
but he organized showings all across Canada, travelling projectionists in schools, and libraries, and church halls. That was his concept. We would have between 80 and 100 travelling projectionists. We had about 100 field projectors. Because we had priority with Munitions and Supply, we got them in batches from Bell and Howell primarily. Yes, any of these field people who I met, I was much impressed with their dedication too. It wasn't an easy job to take a $60 \mathrm{lb}$ projector and travel 45 miles on a winter night, climbing up three flights of stairs into a hall. They tended to be activators, they brought forward discussions, they didn't just say "this is the hog self feeder" and sit down. They tried to promote some thought about research and various things. I think they were a great credit to the film board.

One of Grierson's basic problems was that he was at his very best in a small group of people, he didn't understand expanding organization, because then you'd have to have -- "personnel has to do this' and auditors must do this'... he could ignore that kind of thing, and I guess that was to his peril. You had 700 people on staff at the end of the war...they had no papers... it was all that casual. And of course he needed that personal attachment, as I think most creative people do... It's like running a factory, in a sense when you get so many people. and it certainly makes it difficult.... you sort of lose the control that you feel you have to have, not the control of minds and opinions of people, but the control over what you want to do. How many directors say today, for example, they never really end up making the film they wanted to. Why? Because they have a hundred people around the cameras doing different things and different ideas and trying to get them to think and feel the same way is practically impossible.

This is a bad lesson for a young creative person who feels that the total message is in their soul. You have to consider that it doesn't mean anything if nobody sees it. And first thing you know you are getting an audience reaction and they don't like that much. I think the camera, the sound systems impose limitations. You just didn't have the same kind of freedom. On the other hand, you couldn't have people talk at the camera all day. You had to get action. You had to illustrate the background. This was one of the great problems of many people -- separating personality from backgrounds. If you are going to tell a story all across Canada, make sure that you have a shot of a wheat pool and this and that, and a harvester, in addition to a farmer. You couldn't just isolate it or personalize it to that kind of extent.

Today's generation, and even the one before that, after the war -- if you say now we'll show you Churchill's Island and all these films the Board did at that time with Grierson and then Lorne Green comes on with his booming voice... audiences are horrified. They think that's terrible, that's obviously propaganda, they're shouting it at us... quite forgetting that you don't get commentaries today which are delivered in this way but at that time it was accepted style. But I point out that that is what audiences really expected, and if they hadn't been that way they would have thought something was wrong. With respect to Lorne Green, he was known within the shop as the voice of doom because of this, as in the March of Time which today's audiences have not seen... it was an established way of doing things, and speaking from the top of the mountain and that sort of thing. You couldn't get an incipient kind of person, who says, "I think we're doing rather well in the war"; you had to be positive. There was so much conflicting information coming in that we weren't always winning and you had to have this real focal point. It was also a question of morale. The public wanted to somehow or another lift its spirits somewhat.

So the year passed, Grierson was gone, and we went through a number of discussions as television was coming along, and again, Ottawa in those days was small-town, so we would meet in Davidson Dunton's apartment, and then a committee would be struck. One of the problems, of course, is that we were facing a 10:1 ratio -- there was always ten representatives of the CBC for one person on the film board, and it became obvious that we had good relations with the technical people at the $\mathrm{CBC}$, but they wanted to do their own thing, and they had their concepts and they wanted their own films and yes, that was a sore point. However the problem was some of the things that they could demand of us, we obviously could not respond. We couldn't say we will process all your news to meet a six o'clock deadline. You have to have that, so it became sensible for them to have a processing lab and to set these things up. The lab also, if you remember the days of hot kinescopes, did these immediate transfers, it was before Ampex and the magnetic recording, but the "kinnies" were the princes of the program, of the line, program of a sense, so there was no hope we could cover all those, and we struck a compromise by developing a travelling video crew who covered various points in Canada and they produced about fifteen minutes every week, in and out. 
People like Bernard Devlin were very much involved and Fred Davis was our MC, that and one cameraman was the crew pretty well and then there was a French version of that called "survive" I believe, but it was obvious that it was a running battle, certainly the fact that we did not like to insert commercials. We were very reluctant to do that, and I think most viewers today still hate these constant interruptions, the front porch and the back porch and the middle part of every television program, if not more, they drag in, and frequently totally irrelevant products to the particular show, but that was a way of earning money. CBC technical staffs, in the early days, thought there was nothing to filming because they visualized a radio studio with a camera. The programs were scripted, they were reading things off of the tele-prompter; what else would you ever need in the way of film? And it took a long time before they began to develop their own facilities for drama and the various other kinds of activities. Perhaps the saving grace of film for television was the athletic events, big four football was important and that was a script that wrote itself. You just had to have enough cameramen there and some pretty deft editing and it worked. So that was a bit of a blow to what was the role of the Film Board. I think to counter that was a growing desire to go to the feature. They thought "we have no access for our shorts, we don't have any of this, let's make a feature." Well, it produced some interesting films like Nobody Waved Goodbye and Drylanders.

There was a kind of disillusionment with the 'old-time information film' as such, and I think that was rather sad. Now we had been looking at the possibility of a new building from immediately after the war. We had an architect on staff, I found to my amazement, in the version of Hayzen Sice, who turned up from our Washington office and started drawing plans. Now, I think that I interviewed Hayzen or worked with him on about 8 sites in Ottawa. Every time there was a possibility of a site, triangular, round, whatever, we would do a revision of the building. And if you remember that time, if I'm not mistaken, Ottawa was strongly under the influence of the Greiberg commission, which was going to redesign Ottawa. It was going to change it from a small town into a city and I think that the war contributed to that. Hayzen would follow this sort of thing and he'd hear about how there would be some public land, here there or whatever.

Now sometimes you looked at all this planning we did as being rather silly, cause you didn't expect it, and on the other hand it was marvellous exercise. You have to know what you really want, what can you do without, and I guess the film board's building in Montreal came as a result of the Vincent Massey commission, which very strongly recommended that we have suitable quarters, and of course he had been a patron of the film board from virtually year one, a strong influence, and it took words from people like that; we couldn't do the selling job -- we'd had a successions of ministers who really I guess regarded us as sticky fly papers that they couldn't get rid of. We didn't have the stature of national defence so we were only living from year to year, but his report was very convincing and the government accepted it. Several years later we found ourselves in Montreal.

However I wanted to remain in Ottawa as did many of us. There was a great deal of internal debate on that but I don't think the move to Montreal was sensible, as I mentioned earlier, $30 \%$ of our production business came from departments in Ottawa, and here you are moving away from your largest market, and you have no mandate to open up a new market in Montreal. So it really made no sense other than yes it expanded the opportunities of French production, it was said to be a deeper cultural experience. I think that's true but rather one sided. as we found out, it was a French cultural experience we were moving into. we tried desperately to do other site selections that would have probably fitted our needs but to no avail.

So we got our move over. I think at that time we were sensing the change in pressure as to the kind of production, certainly there was more pressure to do feature films, but we mentioned some of the complications of that. there was a much stronger pressure to give more money to the French production unit, which is not unknown in Canadian history. and they were really looking for a totally independent operation. Had we not had a film commissioner of the quality of Guy Roberge, whom I respect as one of the best, he was our transition man, and he was fair. He'd tell you where to go, he'd tell his French associates where to go because they had an unfortunate little system of revealing things to the press. Every once in a while a memo would float down and I guess it was maybe a way of life. They felt they were fighting their own kind of battle for identity, relations were not great. We worked together, we had brought down $20 \%$ of our staff out of Ottawa; they were French, Ottawa area French.

I think that the Board became weaker; the appointments for film commissioners were mere appointees they 
weren't people of great distinction -- and having an English and a French commissioner, trying to show that they were separated. The last year or so that I was there I was in Ottawa a good deal of the time working for the Department of Communication on some educational applications and for the first time in my life I didn't care as much for the film board, you weren't as excited about going there. And the thing that really turned me off finally was the offer to send my wife and I to live down in Quebec City to take French. And I was two years away from retirement. This is a stupid waste of money. But the Film Board today... just to wrap up... I find that I would be a total stranger, so I wouldn't want to judge... from what I see about changes that have been made I notice that the film commissioner has lost the powers under the national film act to advise the government on policy. Now you seem to find a committee in which the film board may not have any representation.

I think that the Board's role is becoming more tentative. You now are just a job you're getting, half hour here, and half hour there, and what do you say about production today? It seems as though the board has broken itself up into fragments -- you've got the French unit, the women's unit, the films of colour unit, others too, you know, an Indian unit, the Eskimo unit, whatever you want to tape... I guess I have a slightly different take on that, just in this sense -- a long time back I remember attending a citizenship court here in Kitchener, and they made a special point of saying that Canada was a cultural mosaic... Can you ever have a common voice saying this is Canada? I really have my doubts. I still think the Film Board has talented people but I don't know if whether its mandate is as clear to them as it once was. Remember -- to explain Canada to Canadians and to Canadians outside of Canada. Maybe those were simple years. you could really say "this is what I want to do"... but I think life is more complicated. I would not want to be back at the Film Board. I like to try and employ people on the basis of merit.

The Film Board seems to be fading from the public's consciousness, brought about by many things -- including loss of field office, they were part of your catalytic process. I think the film councils, they all played a role in maintaining a focus. now maybe their role is no longer necessary -- probably TV killed all that. if you want a film on nursing, go over to the library and get out the one made by the American medical association. you don't depend on homegrown attitude. But maybe that's evolution, we don't know. I couldn't live through an experience at the film board without absorbing an awful lot of this, and it takes a little bit of prodding. I must say, it was like a flashback. But its over and I have no regrets. I feel sad, but I don't really know what's happening there anymore. And I don't think any of us are really... I think the last of my personal contacts has left, that is who held any sort of senior position. And I think, again only repeat this, but I have a sense that they've lost their mandate. But I'm glad to look back and remember, and tell people, that I was one of the disciples. And I guess that wraps it up.

Gerald Graham was Director of Technical Operations and Research at the NFB 1944-64. He is the author of Canadian Film Technology (1896-1986), published by the Associated University Press.

\section{(2) GRANT McLEAN}

I was living in Ottawa where the Film Board was located and I came to know Grierson through my uncle. I was always interested in photography so I found a position with the National Film Board as cameraman or assistant cameraman. Then I went to Hamilton, Ontario and built calculating machines for Remington-Rand for six months. I returned to Ottawa to be an assistant cameraman. It was the time when Grierson brought in Roger Barlow from the States and I trained under him and Boris Kaufman. So that was the beginning. The Film Board was in an abandoned sawmill next to the French Embassy and I'm sure we were an eyesore for them. But all of this was during the war. The Film Act which was passed September I think, the first, 1939, and then the outbreak of war was September 3, 1939. The Film Board became a sort of war agency, an information agency using documentary films. Then the Board took over, you know, the motion picture bureau and that gave Grierson the machinery to make films. We didn't have many Canadians who were trained in film then. He brought Evelyn Spice who became Evelyn Cherry, over from England where she'd been making films. He brought in Ross McLean who was working for Vincent Massey in London and who had delivered a scathing report on the quality of Canadian documentary films before Grierson. He knew, I think he needed a Canadian assistant commissioner. So the Film Board really started with four or five people including Tom Daly... I think there was Ralph Foster who went on to become Film Commissioner in Australia. As I said I trained under Barlow and Kaufman and eventually was a cameraman for quite a 
number of years and then became head of the camera department and director of photography.

We were set up as two or three units under executive producers but they didn't have a program director at first and the first major program director was Donald Mulholland, a job that I took over when he died of cancer. I was director of production for eleven years, a longer period than anyone else who held that post before or since. I remember Grierson in 1964 saying that the previous decade of the Film Board was the most creative and productive in the Board's history. And I was pleased that I was director of production for all those years. It was an unusual period in the Board when you did many things. I was at the Film Board for 26 years but I was a cameraman, director of photography, writer, director, producer, executive producer, assistant commissioner. And I produced hundreds of films in those various capacities.

In 1945 I went to China to make a film about the country and its people and politics which caused a lot of controversy. China was isolated at that time, the Americans considered it the "red menace" but I didn't. I had been called twice by the United Nations to do work for them and the first time was when I went to China in the fall of 1945 to produce newsreels and films for UNRRA, the United Nations Relief and Rehabilitation Administration. The most memorable of the three films I made there was The People Between. The title stems from the idea that the people were torn between the two ideologies, there were two governments in China, the Communist and the National. My theory was that the people were being exploited by both forms of government.

The Nationalists went out of course in 1949 but in the meantime in order to get sequences for my films, I wanted to shoot in Changsha, Hunan province, the Communist stronghold in South Central China. I got to know Zhou Enlai who later became the Premier of China. He gave me a letter which I have to this day giving me authorization to go to Hunan, and be given everything I required. That was great, but I also needed to get there during the Chinese Civil War. I knew General George C. Marshall of the Marshall Plan fame, who was in China on an American attempt to get the two sides to co-operate, a well-meaning but rather naive concept in my opinion. But anyway, Marshall loaned me his plane and pilots one weekend to fly me into Hunan. And when I finished my shooting I was lucky enough to be able to fly out with Madam Sun Yat-Sen (Soong Ching-Ling) and Lady Cripps. They were co-chairs of British United Aid to China.

I had come to know Sir Stafford Cripps in England during the war when I flew over in the first Canadianbuilt Lancaster and he was Minister for Air, at that time. But Churchill shortly after put Beaverbrook in charge of air production. And Beaverbrook was a powerhouse and the British production of airplanes soared enormously. At any rate, having known Madam Sun Yat-Sen I was able to get out in a matter of hours rather than taking weeks to walk out which I didn't look forward to. The second time the UN called on me was to go to Korea and cover the Korean War. Designated countries were chosen to send director-cameramen for a period of six months and during my period we were in a small perimeter around Pusan. I joined the US Marines in Pusan, and went with them up the coast so I could cover the invasion of Inchon. And then the war settled down for a time at the $39^{\text {th }}$ parallel.

Obtaining supplies was difficult and I always carried a great deal of film and I guess, the principal problem I had was to get it back to Canada for processing. I was terrified getting it processed in China because of the captured and out-of-date Japanese chemicals and also I didn't want to have the Kuomintang censor my material. So I was fortunate and I shipped it so many different ways, you know with people going back and forth and I never lost any. But you're also on tenterhooks that you'd lose two or three months of your work. I used principally a British camera which had to be taken apart and cleaned almost daily because of the dust. I had a smaller German combat camera, and an American Aeroflex. So those were my cameras. They were clock wound because I was shooting in places where I'd never find batteries. And batteries in those days were heavy lead batteries, you didn't have the nickel cadmium batteries at that time. I was there for a year and-a-half. That's a long time! I felt I had become a different person! And finding food wasn't easy.

The best Chinese food of course is in the South. Shanghai wasn't noted for its food, then. And it was a difficult time to live. I always spent most of my time in the interior. There the food was even worse and not as much of it. You know, I covered the famine in Szechuan province and the people were eating the bark off trees and whatever. It was a tragic period. But you could be sure that the soldiers ate well. Then when I returned to Ottawa and put it all together and it was finished, there was a big fuss in the House over it because of complaints from the Americans, about Canada "spending money on red propaganda." 
I produced three films from the material I shot, the most noted one being The People Between and that one the Americans objected to. The American channel lobbying was headed by Senator Patrick Hurley and he was a very powerful figure. He leaned on the Canadian government to ban the film and it was in fact banned. And it wasn't shown until it was well out of date many years later when it was released to Film Societies as an example of documentary film making. And at that time when I finished those films, I was made executive producer of E-Unit section of the television board. There was A, B, C, D, E, F... C was the theatrical unit with Nick Balla and D was sponsored unit under Peter Jones; sponsored meant films mostly made for government departments. The Film Board was really set up to do sponsored films instead of each department making its own deals, to co-ordinate and to put films out for tender and so on. And to regularize the whole process.

I think many people at the Film Board forgot that was our raison d'être, and thought of it as a cultural agency which it never was, culture meaning arts and entertainment, and one in which the government would have an arm's length relationship. The governing board had three civil servants on it including the clerk of the Privy Council and several members of cabinet. They did not interfere, they really didn't. I have to give them credit. They were really more interested in the efficiency of the operation. Only once in the first days did we have a difficult member. He was the Head of National Defence, General LaFleche and he hated Grierson and was always upset that Grierson was managing to get supplementary votes to add to his general vote. So he asked his executive assistant who happened to be my father Allan Grant McLean, to go to the Film Board as the executive director and make sure Grierson didn't get all this extra money. Well, it didn't work out that way. My father was enamoured with Grierson and really showed him how to get more funds.

You've noticed of course that in the last few years the revisionists have been having a go at Grierson being the tool of the capitalists and imperialists and all that sort of thing. But also the charge that he discriminated against French filmmakers from Quebec and that he didn't do anything about making feature films as if, during the war, you know, he had the means to do so. It's a total crock. Grierson was certainly not antiFrench -- he thought the Film Board should remain in Ottawa, the nation's capital. And it was a tragedy in my opinion that the Film Board was eventually moved to Montreal because Arthur Irwin got together with Robert Winters and arranged it. He said that the Film Board should be removed from the immediate scrutiny of parliament but I believe that any information agency should remain under the direct scrutiny of parliament because that's the democratic way. I think the Film Board in spite of the heroic efforts of many people eventually became "sacked" by the Montreal location. Grierson was very careful to recruit from the Maritimes and the West because as he said, you're willy-nilly going to get enough people from Ontario and Quebec, you have to make an effort to get people from the West and the Maritimes.

But of course today, the Film Board has all these regional offices which was a twisting of the original idea. The regional offices were set up originally to send in ideas from the different regions. The regional units were to send in ideas and also if they found a bright young person that they thought had promise in the field to see if the Film Board would employ him. There were to be offices of one person with a secretary. And this is when you had Peter Jones in Vancouver, Gordon Burwash in Winnipeg, Don Fraser in Halifax and so on. But they were turned into regional production offices which I think was a blunder. You cannot put out films very easily to the private sector when you're making most of them in the regional offices. And when Guy Roberge turned over a third or half, I've forgotten the percentage, of sponsored films to the private sector, I think it was the beginning of the end because that was really the Film Board's existence. That solidified the impression that a certain group, in this instance the Board, was really an arts organization and sponsored films by other government departments were kind of dirty anyway and they didn't want to get their hands soiled.

I am not sure about the year, I think it was 1983, Pierre Juneau was head of the CBC and I was living in Dallas. He asked me to come up to Ottawa and do a study of the Film Board's production for him. So I did that and whereas we year after year after year produced 150 original titles a year, they were down to four or five and many of them were co-productions and they didn't keep the staff at a level with their income. You always have to maintain at least $25 \%$ of your money free for buying new stock and paying actors and whatever. And if you don't do that you just shrink and start producing fewer and fewer films. And as I say by 1983 they were down to four or five. And I remember Ann Claire Poirier, one of the best filmmakers at the Board was told when she went up with a new idea, that it wasn't her year to make a film, to go home and 
her cheques would be sent to her at home. I don't think the production has increased significantly since then although I haven't been in touch with it. But I, I've come to the conclusion that all organizations, all Acts of Parliament should have some set provisions in them that when organizations have ceased their usefulness, I think they should be disbanded and not simply carry on at public expense no matter how unproductive or useful they are.

Looking back I remember the great days and John Grierson, was I think a heroic figure, and his death was a shattering blow to me. He wrote me a letter from the hospital in Bath a day or two before he died which I always treasure. Speaking of him, I don't think we mentioned that time after the war which is referred to as the "witch hunt" period and put, paid to Grierson's career here. He had been hired by UNESCO to go down to head up its film unit but as soon as this "red scare" came up his chances were gone and that's when he went back to England. It was a dreadful period in Canada. The US had just gone through its witch hunt period with McCarthy. Dreadful period. And Canada followed that, I guess they felt "we've gotta do it, too" and we did it in the Canadian way, we did it more quietly and Grierson was, understandably, very haughty in his treatment of that commission, and I think they resented it. And it is also interesting to remember this was, when Ross McLean was Commissioner, he was asked to fire thirty or forty people who were supposedly Communists and this was based on the RCMP reports.

Ross McLean, I thought showed great moral courage by refusing to fire them unless the RCMP turned the files of those people over so he could peruse them. Because everyone knew that much of what was in the RCMP files was rumour, hate letters, no facts, whatever. And they refused to give him that information and so he refused to fire anyone. And so he wasn't reappointed and Arthur Irwin who was head of Maclean's magazine was brought in as Film Commissioner to "clean it up." And so he asked for the files and he was not given them either but he fired three people which seemed to convince the government that he'd cleaned up the Board and so Irwin was then made High Commissioner to Australia. Since I knew those people, I knew they weren't Communists.

But it wasn't until Irwin wrote his own book years later, I discovered they also refused to show him the files. But he wanted to go to Australia as High Commissioner. It was a sad period not only for the Film Board but all of Canada. And part of that deal was the fact that the Board's new headquarters were built in Montreal; a sad mistake as I have said. But it did mark the beginning of the Board's dramatised longer films called "features," notably Don Owen's Nobody Waved Goodbye, Don Haldane's The Drylanders, and Gilles Carle's The Merry World of Leopold Z, striking dramas reflecting the documentary social realism of the NFB. These might just as well have been made out of a new studio in Ottawa. This perhaps is a good point to end on because although they didn't make much of an impact at the time with so many American films being shown, as the years have passed, their appeal to audiences remains strong.

They were important films and I thought the Film Board's role wasn't to make either short films or long films, it was to make a certain kind of film. And if a film was of that genre then its length would be dictated by the film itself. I don't think you set out to make feature films you know... or short films. Of course, the demise of the short film in cinemas was a tough blow for the National Film Board because we had two theatrical series which did very well really. Now, take today, people ask me do you think the Board is being run properly? I come from a period when organisations like the Board were run by people who knew something about film. I think the people who have been appointed the last two or three years have absolutely no background in any media and I don't understand what they were supposed to bring to it other than setting up a unit for every conceivable group. Everybody's unit, I think. I mean if someone can make a film it doesn't matter if they're a man or a woman. If they're a good filmmaker, that's what's important. They don't have to have their own special division. They then start making films for themselves and not for the country.

I find it sad when Canada used to have a very strong and effective public service exemplified by people like Gordon Robertson, the clerk of the Privy Council. Was it the Bilingualism Act that meant that you're not going to get any Maritimers or Westerners in the public service, was the cause of this decline? But I do know it has declined and the standards are much lower than they used to be. It would be too easy to put it off as being the nostalgia of old age to think that it is the standards which have changed. It's a sad note but it makes an appropriate ending. Because that's what the situation is.

Grant McLean began his association with the NFB in 1941 in the camera department, where he also became 
a writer and director. In 1943 he went to England to film Target Berlin, one of the Board's great war documentaries. He also spent time in the Eastern Arctic and in the Fall of 1945 went to China during the Civil War as related here. He became executive producer for NFB-TV in 1955 and then for ten years Director of Production. He became Assistant Film Commissioner, then finally Film Commissioner (1965-67). Later he left for the private sector and founded the Visual Education Centre in Toronto.

(The Conversations will continue in the next issue.)

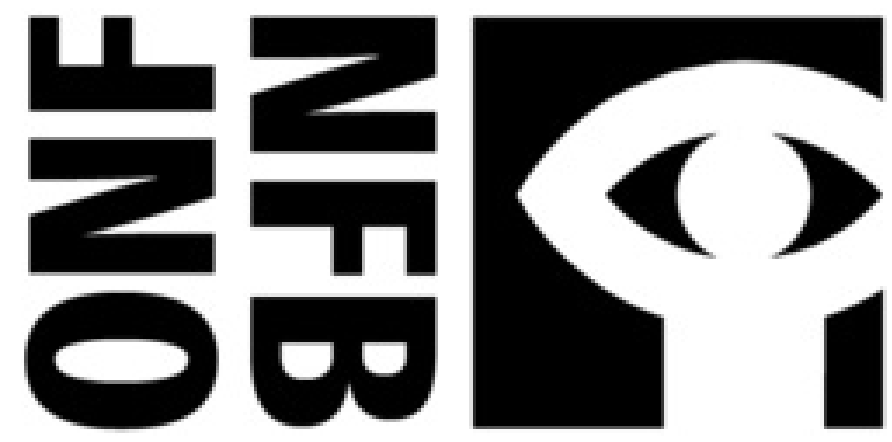

Figure 1: National Film Board of Canada logo

\section{Author Information}

Gerald PRATLEY, OC, LLD, started his career as film critic with the CBC. In 1969, he founded the Ontario Film Institute which he directed until 1990. He has written several books and numerous articles on film, including Torn Sprockets, a history of Canadian cinema. He taught Film History in universities in Toronto and Waterloo, Canada and holds three honorary degrees from Canadian and US universities.

Gerald A. Pratley (1923-2011) was born and educated in London, England, and came to Canada in 1946. He started working in Toronto for the $\mathrm{CBC}$ as a scriptwriter. He was drawn toward working in motion pictures, and became, in 1948, the CBC's first film critic and commentator.

Gerald Pratley broadcast three programmes a week, Pratley at the Movies, The Movie Scene, Music From the Films, and others, until 1975. During this time he also became the first post-war chairman of the Toronto Film Society, chairman of the Toronto and District Film Council and co-founder of the A-G-E Film Society and correspondent for international magazines such as Films and Filming, Film In Review, Variety, Hollywood Quarterly and International Film Guide. During the 1950s he wrote for Canadian Film Weekly and Canadian Film Digest.

He became known as a speaker on all aspects of motion picture art and industry, and was invited to teach film history at the University of Toronto, York University, University of Waterloo, Seneca College and Ryerson Polytechnical University, with individual lectures being given at many other Canadian and US universities and colleges. He has served as a member of various judging panels of competitions and festivals, being one of the members of the first Canadian Film Awards in 1949.

From 1970 to 1975 he was the director of the Stratford (Ontario) International Film Festival, and from 1969 to 1976 he was Chairman of the International Jury of the Canadian Film Awards. He has attended all the world's leading festivals of film, and in particular, for 30 years, the Cannes Festival as CBC correspondent. He has written six books, The Films of Frankenheimer: Forty Years in Film; The Cinema of John Frankenheimer; The Cinema of Otto Preminger; The Cinema of David Lean; The Cinema of John Huston, and Torn Sprockets, a history of the Canadian cinema.

Gerald Pratley has served on the Advisory Boards of the film departments of Ryerson Polytechnical University and Humber College, and as a member of the programme committee of TV Ontario. In 1968 he became the founder-director of the Ontario Film Institute of the Province of Ontario, an organization which has 
distinguished itself in archival holdings and public service and is known since 1990 as the Cinematheque of Ontario. He taught Film History courses at the Department of Film and Photography, Ryerson Polytechnic University, Toronto and the University of Waterloo.

In 1984, Gerald Pratley was made a Member of the Order of Canada and in 2003 Officer of the Order of Canada for his service to Canada through film appreciation. He holds Honorary Degrees in Letters and Fine Arts from York and Waterloo Universities (Ont., Canada) and Bowling Green State University (Ohio, USA).

In 2002, Gerald Pratley received a Special Genie Award from the Academy of Canadian Cinema \& Television in recognition of his lifelong dedication to the promotion and his exceptional support of Canadian cinema.

He died on 14 March 2011 in Ontario, Canada. 